Badruzzaman

\title{
IMPLEMENTASI PENDIDIKAN AGAMA DI DAERAH PASCA KONFLIK \{Studi Kasus di Kota Ternate Maluku Utara)
}

Oleh: Badruzzaman

\begin{abstract}
This research aims to describe the implication of social-religious conflict to education of religion (formal and informal) implementation. This was conducted at Ternate, North Maluku. Data was collected by depth interview and observation.

This research indicates that social-religious conflict was occured at 1999 fisically has no impact to educational process. But, this conflict had give impact to learning process of religion education. Especially, to Christ and Katolik schools. These schools became refugee camp.

Nevertheless, local government regulation to education of religion implementation have been increase after conflict. But, that regulation seems do to certain school.
\end{abstract}

Key word: implementation, education, religion, conflict

I. PENDAHULUAN

enelitian ini bertujuan untuk mengetahui dampak konflik bernuansa agama
terhadap pendidikan agama, dan implementasi kebijakan pemerintah
terhadap peningkatan mutu pendidikan agama di Kota Ternate.

Penentuan tujuan penelitian tersebut didasari oleh berbagai literatur sejarah menyebutkan bahwa konflik atau perang lebih banyak mendatangkan dampak negatif dari pada dampak positif. Kehancuran harta benda dan jatuhnya korban manusia merupakan akibat konflik yang sangat nyata. Institusi pendidikan tidak luput dari kehancuran akibat konflik. Konflik bernuansa politik yang telah melanda Aceh telah menghancurkan ratusan sekolah baik di tingkat SD. SLTP dan SLTA. Selama perang bcrkecamuk, 1998-2003 sejumlah 546 sekolah terbakar (data Dinas Pendidikan Aceh). Dapat dibayangkan bahwa, disaat-saat eskalasi konflik 


\section{Badruzzaman}

di Aceh tinggi, tahun 2000, sejumlah 514 guru meninggalkan Aceh karena alasan keamanan (Kompas, 8 Februari 2000). Dalam kurungwaktu itu Dinas Pendidikan Aceh melaporkan, bahwa nilai ujian akhir palaja SD sampai SMA berada pada posisi 22 dari 27 propinsi.

Beberapa fakta tersebut menjelaskan bahwa konflik atau perang telah memberikan dampak mematikan institusi pendidikan. Saat itu terjadi ketimpangan proses sosialisasi sekundertidak terhindarkan. Inilah yangmenjadi katalisator sulit berkembang dan dan berfungsinya tatanan sosial.

Pada sisi yang lain, kita pun merasakan bahwa pendidikan agamajuga ikut mendapat dampak dari konflik sosial tersebut. Data tentang dampak konflik terhadap pendidikan agama belum kita dapatkan secara utuh. Hal ini sangat penting untuk lebih meningkatkan pembangunan dibidang pendidikan agama yang selajutnya merumuskan model pendidikan agama yang dapat mencegah timbulnya konflik bernuasa agama.

Pendidikan agama yang diberikan di sekolah-sekolah kita pada umumnya tidak menghidupkan pendidikan multikultural yang baik, bahkan cenderung berlavvanan. Akibatnya, konflik sosial sering kali diperkeras oleh adanya legitimasi keagamaan yang diajarkan dalam pendidikan agama di sekolah-sekolah daerah yang rawan konflik. Ini membuat konflik mempunyai akar dalam keyakinan keagamaan yang fundamental sehingga konflik sosial kekerasan semakin sulit diatasi, karena dipahami sebagai bagian dari panggilan agamanya.

Kenyataan menunjukkan bahwa pendidikan agama masih diajarkan dengan cara menafikan hak hidup agama yang lainnya, seakan-akan hanya agamanya sendirilah yang benar dan mempunyai hak hidup, sementara agama yang lain salah, tersesat dan terancam hak hidupnya, baik di kalangan mayoritas maupun yang minoritas. Semangat pendidikan keagamaan yang sempit ini, sudah barang tentu berlawanan secara fundamental dengan semangat pendidikan multikultural, dan akan memperlemah persatuan bangsa.

Hasil penelitian ini diharapkan dapat dijadikan dasar dalam upaya peningkatan mutu pendidikan agama, terutama terhadap perbaikan kebijakan pendidikan agama di daerah pasca konflik. Selain itu hasil penelitian ini pula diharapkan sebagai emrio terhadap upaya penyusunan muatan multikultural pada pembelajaran jenjang pendidikan dasar dan menengah.

Penelitian ini menggunakan pendekatan kualitatif dengan sasaran penelitian adalah sekolah-sekolah agama seperti Madrasah, sekolah Katolik, sekolah 
Protestan dan lain sebagainya yang terdapat di daerah penelitian. Data yang diperoleh dari Pemerintah setempat, masyarakat, pengajar, dan pengelolah lembanga pendidikan melalui teknik wawancara terstruktur dan mendalam interviu dan studi pustaka dianalisis secara deskriptif knalitatif menurut pengelompokan data, kemudian diberikan elaborasi dan inteipretasi yang relevan. Kemudian mereduksi data, selanjutnya menyusun ke dalam satuan-satuan, lalu dikategorisasi menurut metode analisis yang digunakan.

\section{TEMUAN PENELITIAN}

\section{Setting Sosial Lokasi Penelitian}

Sistem kemasyarakatan pada zaman Pra Islam di Ternate mendiami suatu tempat tinggal, yang mereka sebut dengan istilah Gam (Kampung), warganya terdiri dari beberapa keluarga/kerabat yang dalam istilah disebut Sao (marga), yang dipimpin oleh seorang Fanyira. (Kata Fanyira adalah singkatan dari Ngifama-nyira). Masing-masing kepala Sao dipimpin oleh seorang Momole (kepala kampong). Di samping sebutan sebagai Kepala Sao untuktiap-tiap Sao, kata Momole berasal dari kata Tomole yang mempunyai arti "kejantanan atau kehebatan" yakni orang menjadi pemimpin karena mempunyai kelebihan dan kesaktian dalam berbagai hal. Kelompok masyarakat waktu itu masih menjalankan kepercayaan primitif, dan kadang-kadang masih terjadi pertentangan dan permusuhan dalam hal perebutan hegomoni. Dengan demikian maka di Ternate pada zaman pra Islam terdapat' 4 orang momole. Seorang momole yang diangkat berdasarkan kharisma yang dimilikinya. Setelah masuknya Islam, maka sistem pemerintahan momole berubah. Keempat momole tersebut, bergabung dan dipimpin oleh seorang Kolano. Pasa awal sistem ini, struktur pemerintahan masih sangat sederhana.

Bersamaan dengan masuk dan berkembangnya agama Islam di Ternate, maka berkembang pula system Pemerintahan Kolano, seperti jugaTidore, Bacan dan Jailolo. Keempat Kolano membentuk konfederasi persekutuan empat kerajaan di Tuanane, Pulau Moti, yang kemudian dengan sebutan persatuan Moloku Kie Raha. Ternate pada waktu itu dipimpin oleh Kolano ke-7, yaitu Kaicil Aija Alias (Kolano Sida Arif Malamo). "Kolano Madopolo" yang memimpin persekutuan empat kesultananan ini. la dinobatkan sebagai Kolano pada tahun 1322 dan memerintah selama Sembilan tahun (1322-1331).

Ternate adalah sebuah kota otonom yang dibentuk dengan Undang-Undang Nomor 11 Tahun 1999 tentang Pembentukan Kotamadya Ternate dan diresmikan 


\section{Badruzzaman}

pada tanggal 27 April 1999. Kota Ternate yang memiliki luas wilayah daratan 249,75 km2, secara Administrasi Pemerintahan, Ibukota Propinsi Maluku Utara, terbagi atas 4 Kecamatan dan 63 kelurahan.

Kondisi penduduk kota Ternate dilihat menurut jenis agama yang dianut pun memperlihatkan kondisi yang normal. Jumlah penganut agama Islam yang sejak masa orde baru memiliki peringkat tertinggi masih tampak sampai saat ini. Jumlah penduduk Kota Ternate saat ini adalah 157.575 jiwa. Penganut agama Islam tampak terkonsentrasi di Kecamatan Ternate Selatan dan Ternate Utara, sedangkan Penganut agama Kristen lebih dominan bermukim di Kecamatan Pulau Ternate.

\section{Profil Konflik/Kerusuhan Bernuansa Agama}

Wilayah Maluku Utara meliputi beberapa pulau antara lain P. Halmahera, P. Tidore, P. Ternate, P. Makian, dan P. Morotai. Berbeda dengan konflik di Maluku bagian tengah dan tenggara, motif awal dari konflik di Maluku Utara ialah persoalan identitas adat dan wilayah. Awalnya, yang berseteru hanyalah penduduk dari Pulau Makian yang karena evakuasi bencana alam harus mengungsi dan ditempatkan pemerintah ke pulau Halmahera yakni di kawasan Kao. Perseteruan itu diawali oleh kontroversi putusan pemerintah PP.42/1999 untuk memekarkan Kecamatan Kao menjadi dua kecamatan yakni Kecamatan Kao (berisikan desa-desa penduduk Asli Kao) dan Kecamatan Makian-Malifut (berisikan penduduk Makian) dengan merubah 5 desa dari Kecamatan Kao untuk bergabung dengan desa-desa vvarga Makian yang note bene adalah kaum pendatang di Halmahera. Pemekaran kecamatan yang diikuti perubahan status administratif wilayah kelima Desa Kao ini kemudian menjadi masalah. Kelima desa ini menolak bergabung dengan orang-orang Makian karena mereka terikat kesatuan adat dengan sejumlah desa kao atas dasar sumpah leluhur. Tanpa memperdulikan keberatan ini, pemerintah secara sepihak meresmikan berdirinya Kecamatan Makian-Malifut pada tanggal 18 Agustus 1999 (siang). Entah apa sebabnya, malamnya terjadi penyerangan warga Makian terhadap dua desa Kao (desa Sosol dan Wangeorak) dari 5 desa Kao yang menolak kebijakan pemerintah daerah tersebut. Secara kebetulan masyarakat Makian beragama Islam sedangkan kedua desa Kao yang diserang ini berpenduduk Kristen.

Penyerangan oleh masyarakat Makian-Malifut ini kemudian dibalas oleh bantuan warga masyarakat dari Kao Barat dan Kao Timur yang beragama Islam dan Kristen sekitar 1000 personil. Akibat konflik 4 hari (18-21 Agustus 1999), sejak hubungan harmoni kedua suku ini berubah menjadi hubungan konflik. 
Masyarakat Kao menuntut agar masyarakat Makian yang nota bene adalah pendatang di Halmahera segera keluar meninggalkan vvilayah Malifut yang merupakan wilayah leluhur masyarakat Kao. Selang sebulan (24-26 Oktober 1999), terjadi lagi konflik kekerasan antar Makian dan Kao yang dimulai dari agresi sekelompok massa Makian ke dalam wilayah Kao. Akibatnya terjadilah perang etnis yang memaksa masyarakat Makian mengungsi keluar dari wilayah Malifut-KAO.

Motif konflik Etnis ini kemudian direkayasa untuk berubah menjadi konflik agama pada peristiwa di Tidore. Rekayasa ini terlihat dari surat palsu dari ketua Sinode GPM yang berbau provokasi konflik agama dengan sasaran awal adalah etnis Makian. Surat yang kebenarannya telah dibantah oleh ketua Sinode GPM maupun MPS GMIH memang digunakan untuk membangkitkan dan mengiring kemarahan massa ke dalam aksi penyerangan, pembunuhan dan pembakaran 3 gereja dan rumah-rumah orang Kristen. Akibat kerusuhan ini maka penduduk Kristen di Tidore di evakuasi keluar dari pulau tersebut.

Dengan sengaja diedarkan surat ini kepada masyarakat Tidore yang dominan muslim dan para pengungsi dari Makian di Tidore, skenario konflik umat beragama berhasil dimainkan di Tidore dan selanjutnya melebar dan meluas ke pulau Ternate dan berbagai kavvasan di pulau Halmahera. Konflik etnis-agama yang berhasil dimulai dari Malifut dan dimatangkan di Tidore tidak berhasil dicegah penyebarannya oleh sultan Ternate yang rupanya rival berat kesultanan Tidore dalam hal kandidat gubenur Maluku Utara. Puncak konflik kedua kesultanan ini terjadi dalam bentuk konflik kekerasan yang dikemas dengan bungkusan konflik agama. Bentrokan kekerasan ini pada akhirya dimenangkan oleh sultan Tidore. Hancurnya wilayah, otoritas dan kekuasaan Sultan Ternate diikuti dengan serentetan aksi kekerasan yang sebenarnya merupakan upaya penaklukan dan penguasaan kesulatanan Tidore atas wilayah Halmahera utara (seperti Kao, Tobelo dan Galela) yang nota bene merupakan wilayah kekuasaan kesultanan Ternate. Dengan mengerahkan masa pendukungnya dari Makian dan para pendukung Jihad, aksi penguasaan-penaklukan ini menjalar hingga pada akhirnya mereka mendapat peiiawanan keras dari masyarakat Asli Halmahera di Tobelo dan Galela yang kebetulan mayoritas Kristen. Perlawanan masyarakat Asli Halmahera terhadap hegemoni Tidore-Makian, rupanya direspons pula oleh sebuah kelompok massa lain yang patut diperhitungkan kekuatan tempur magisnya yakni suku TOGUTIL, sebuah suku asli-terasing di Halmahera. Suku Togutil tidak menganut agama Islam atau kristen. Mereka masih memelihara agama adat yiiang berbau animisme-dinamisme. Keterlibatan mereka dalam berperang melawan pasukan 
Jihad diakibatkan [1] motif balas dendam atas terbunuhnyakeluarga merekayang kawin dengan orang Kristen Halmahera dan [2] motif membela eksistensi diri dan wilayah Halmahera dari ekspansi penghancnran oleh kaum pendatang (Makian, Tidore dll). Karena itu konflik bemuasa agama yang terjadi di Ternate merupakan rembesan dari konflik yang bennotif oleh persoalan identitas/etinik dan wilayah adat yang terjadi di Makian-Malifut melalui Tidore.

\section{Dampak Konflik terhadap Pendidikan Agama}

Kerusuhan bernuansa agama yang terjadi di Kota Ternate pada tahun 1999, memang berdampak terhadap pendidikan agama, baik fisik, pelaku pendidikan maupun proses pembelajaran. Namun dampak tersebut dianggap oleh masyarakat Kota Ternate tidak besar dibanding dampaknya terhadap proses perekonomian, kerusakan fasilitas umum dan peribadatan. Sasaran pengrusakan yang dilakukan oleh oknum yang terlibat konflik adalah mayoritas bangunan yang memiliki simbolsimbol agama, seperti rumah penduduk dan tempat-tempat ibadah.

Seperti diungkapkan terdahulu bahwa masyarakat Kota Ternate mayoritas menganut agama Islam, karena itu tidak ditemukan fasilitas peribadatan penganut agama tersebut dijadikan sasaran kerusuhan. Namun fasilitas peribacjatan penganut agama Kristen dan Katolik hampir seluruhnya menjadi sasaran kerusuhan.

\section{a. Dampak Terhadap Pendidikan Agama Islam}

Kerusuhan bernuasan agama yang terjadi di Kota Ternate, 1999, bagaimanapun berdampak terhadap keberlangsungan pendidikan agama Islam, secara fisik, lembaga-lembaga pendidikan agama Islam di semua jenjang pendidikan tidak mengalami kerusakan akibat kerusuhan tersebut. Hal ini disebabkan oleh karena sasaran kerusuhan saat itu mayoritas simbol-simbol peribadatan dan permukiman masyarakat. Selain itu, di Kota Ternate memiliki penduduk yang mayoritas menganut agama Islam.

Dampak kerusuhan bernuasan agama tersebut pada lembaga pendidikan agama Islam tampak pada semua jenjang pendidikan baik negeri maupun swasta. Padatingkatan madsarah ibtidayah, terdapat 9 (sembilan) madrasah, baik negeri maupun swata yang dibina oleh Kantor Departemen Agama Ternate tidak mendapatkan pengaruh secara fisik akibat kerusuhan tersebut. Demikian halnya pada tingkatan Tsanavviyah terdapat sejumlah 9 (sembilan) Madrasah Tsnawiyah tak satupun ditemukan mengalami kerusakan akibat kerusuhan. Hal yang serupa dialami pada tingkatan Aliyah, terdapat tiga madrasah, satu diantaranya berstatus negeri (MAN Model). 
Badruzzaman

Namun kerusuhan tersebut berdampak pada proses pembelajaran. Terdapat sekian waktu proses pembelajaran di semua jenjang, baik negeri maupun swasta terlienti. Terhentinya proses pembelajaran tersebut diakibatkan oleh karena tak seorang pun siswa yang masuk sekolah akibat kekhawatiran terjadi kerusuhan serupa. Para orang tua siswa mencegah anaknya untuk keluar jauh dari pengawasannya termasuk ke sekolah. Selain itu pihak sekolah memang sengaja meliburkan sekolah untuk lebih mengantipasi kemungkian buruk atau keselamatan siswa bila kerusuhan semakin meluas dan berkepanjangan.

Kondisi ini terjadi sekitartigabulan di semuajenjang pendidikan. Selama tiga bulan masa-masa kerusuhan tersebut proses pembelajaran di semua jenjang pendidikan agama Islam, MI, MTs dan MAterhenti.

Pada proses selanjutnya, dampak kerusuhan terhadap keberlasungan proses pembelajaran berupa pemamfaatan fasilitas pendidikan sebagai sarana evakuasi. Ratusan pengungsi dari daerah-daerah konflik lebih besar seperti dari wilayah Halmahera menempati sekolah-sekolah tersebut sebagai tempat-tempat pengunsian. Seperti misalnya MTs Negeri Tenate, seluruh kelas maupun sarana perkantoran dimanfaatkan oleh para pengungsi. Selain itu beberapa madrasah swasta lainnya turut dimanfaatkan oleh para pengunsi untuk dijadikan tempat bermukim.

Setelah aktifitas pembelajaran berlangsung, yang muncul kemudian adalah dampak psikologis. Sejumlah pelaku pendidikan seperti siswa, guru maupun pengelola madrasah (administrator pendidikan) mengalami proses psikologis yang tidak kondusif. Dampak psikologis berupa tingkat stress para ketiga komponen pendidikan tersebut meningkat. Hal ini disebabkan oleh karena kapasitas kelas yang mayoritas memuat maksimal 40 siswa bertambah menjadi 60 atau lebih dari itu. Sungguh banyak siswa-siswa hasil pengunsian yang ditampung sementara dan diikutkan dalam proses pembelajaran di madrasah-madrasah tersebut. Karena itu para siswa tampak mengalami ketergangguan dalam proses belajar. Perilaku mereka tampak tak dapat dikontrol lagi disebabkan sempitnya ruangan kelas, gerah, panas, ribut dan lain-lain. Hal ini berlangsung di semua jenjang pendidikan agama Islam, MI, MTs, dan MA. Seperti MIN moyaritas menampung lebih seratus siswa tambahan, MTsN Ternate menampung 165 orang siswa tambahan sedangkan MAN Model menampung sejumlah 87 siswa tambahan.

Selain siswa, penambahan jumah guru di beberapa madrasah pun terjadi. Ada sejumlah guru madrasah yang berasal dari daerah konflik yang ditempatkan sementara di beberapa madrasah negeri di Kota Ternate. Seperti MAN Model 


\section{Badruzzamdn}

Ternate kelebihnan guru sejumlah 17 orang, 15 orang diantarannya guru bidang studi umum dan dua guru bidang studi agama. Kelebihan ini disebabkan karena banyaknya guru yang pindah tugas dari wilayah-wilayah konflik seperti dari wilayah Halmahera.

Gurujuga mengalami hal yang serupa, mereka mengalami tingkat stres tertentu disebabkan karenatidak mampu untuk mencapai tujuan pendidikan yang maksimal seperti yang diprogramkan. Hal ini disebabkan oleh karena tingkat perhatian siswa terhadap materi yang diajarkan terganggu karena kelas melebih kapasitas.

b. Dampak Terhadap Pendidikan Agama Kristen/Katolik

Kerusuhan bernuansan agama di Ternate Tahun 1999 sangat berdampak terhadap proses pendidikan di lembaga-lembaga pendidikan yang dibina oleh Kristen dan Katolik. Dampak kerusuhan tersebut hampir disemua aspek pendidikan, seperti sarana dan prasarana pendidikan, tenaga pendidik, siswa, maupun proses pembelajaran.

Secara umum, kerusuhan tidak berdampak terhadap fasilitas-fasilitas pendidikan Kristen. Hal disebabkan sasaran kerusuhan adalah permukian penduduk dan tempat-tempat ibadah, tetapi tidak berarti bahwa tak satupun bangunan-bangunan sekolah Kristen juga turut menjadi sasaran kerusuhan. Bagunan sekolah yang turut mendapat sasaran kerusukan terutama lembagalembaga pendidikan yang berada satu lokasi dengan rumah ibadah.

Satu-satunya sekolah Kristen yang rusak karena menjadi sasaran kerusuhan adalah SMP Kristen. Menurut Kepala Bidang Bimas Kristen/Katolik Kanwil Agama Ternate, bahwa sekolah tersebut merupakan lembaga pendidikan yang dibina oleh Gereja Gemim Ternate, yang terletak selokasi dengan Gereja Gemini Ternate. Karena itu sekolah itu juga turut menjadi sasaran kerusuhan, yang pada fokusnya sasaram utama masyarakat adalah gereja Gemim. Kerusakan gedung sekolah tersebut tidak separah rusaknya dibanding dengan gereja Gemim. Jadi hanya SMP Kristen Gemim saja yang mendapat dampak fisik dari kerusuhan 1999, karena berada di dalam satu lokasi dengan Gereja. Sedangkan sekolah-sekolah yang terletak jauh dari rumah ibadah, tampak tidak mengalami kerusakan secara fisik.

Dampak konflik bernuasa agama itu kemudian berdampak terhadap proses pembelajaran di sekolah-sekolah Kristen/Katolik. Hal ini disebabkan oleh mengungsinya keluar Ternate sebagian besar penganut agama Kristen/Katolik dari Ternate, termasuk guru, murid, maupun administrator pendidikan di sekolahsekolah tersebut. 
Sebelum kerusuhan ada sejumlah 5 sekolah yangdibawah binaan Kristen, 1 TK, 2 SD, 1 SMP dan 1 SMA. Sedangkan 2 lagi di bawah binaan Katolik yaitu 1 TK dan 1 SD. Mayoritas sekolah-sekolah tersebut sampai saat ini belum beroperasi. Pengaktifan kembali proses pembelajaran pada sekolah-sekolah tersebut sampai saat ini belum dimulai. Hal ini disebabkan karena pemungsian sekolah-sekolah itu sebagai lembaga pendidikan sampai saat ini belum dimulai.

Ada sejumlah sekolah sampai saat ini masih difungsikan sebagai sarana umum untuk kepentingan penampungan pengungsi. Para pengungsi muslim yang mayoritas berasal dari Halmahera masih menempati bangunan-bangunan tersebut sebagai tempat bermukim. Diantaranya adalah sekolah-sekolah itu adalah TK Kristen Gemim dan SD Keristen Gemini sampai saat ini masih dijadikan sebagai tempat penampungan para pengungsi muslim dari Halmahera. Karena itu upaya untuk mengoprasikan kedua sekolah ini sebagaimana fungsi sebagai lembaga pendidikan belum dapat dilakukan.

Menurut Pendeta Gereja Sinode Ternate, bahwa masalah utama yang dihadapi dalam upaya mengoperasikan kembali kedua lembaga pendidikan itu adalah pemindahan para pengungsi. Kalau hal itu sudah dilakukan maka proses-proses pengelolaan kedua sekolah itu sebagai lembaga pendidikan, yaitu rehabilitasi sarana sekolah, penerimaan murid, pengangkatan guru dan lain-lain akan dilakukan.

Terdapat pula sekolah Kristen yang berfungsi menjadi sarana pendidikan, namun institusinya lain. Gedung sekolah itu digunakan oleh lembaga pendidikan yang lain. Gedung dan sarana SMA Kristen Ternate sampai saat ini masih difungsikan oleh salah satu lembaga perguruan tinggi, yaitu STIK1P. Selain itu gedung dan sarana Perguruan Tinggi Teologia sampai saat ini juga masih difungsikan oleh Unversitas Muhammadiyah sebagai sarana perkuliahan.

Karena itu, ketidakberlangsungan proses pembelajaran di sekolah-sekolah Kristen lebih disebabkan oleh faktor eksternal dari lembaga pendidikan tersebut yang juga merupakan dampak dari kerusuhan/konflik bernuansa agama yang pernah terjadi di Kota Ternate pada tahun 1999.

4. Kebijakan Pemda Terhadap Pendidikan Agama dan Keagaman Pasca Konflik

Secara umum program pembangunan agama atau kebijakan Pemerintah daerah Kota Ternate, sebagai berikut:

Program peningkatan pelayanan kehidupan beragama;

Program peningkatan pemahaman dan pengamalan agama,dan kerukunan umat beragama; 


\section{Badruzzaman}

- Program peningkatan kualitas pendidikan agama;

Program pembinaan lembaga sosial keagamaan dan lembaga pendidikan tradisional keagamaan.

Sementara Pembangunan pendidikan diarahkan untuk menyelesaikan permasalahan-permasalahan yang menonjol dalam dinamika pendidikan nasional di Kota Ternate yaitu:

- Masih rendahnya pemerataan memperoleh pendidikan ;

- Masih rendahnya kualitas pendidikan dan irrelavansi pendidikan dengan duniakerja;

- Masih lemahnya manajemen pendidikan, di samping belum terwujudnya kemandnMafi dafi'keuhggulan ilmu pengetahuan'dan teknologi dikalangan akademisi;

- Belum sungguh-sungguhnya penerapan pendidikan alternatif bagi anak pengungsi, keluarga miskin dan desa terpencil. Ketimpangan pemerataan pendidikan juga terjadi antar wilayah geografis yaitu antara perkotaan dan perdesaan, serta kepulauan, dan antar tingkat pendapatan penduduk atau pun antar gender.

Program Peningkatan kualitas pendidikan agama di Kota Ternate:

- Menyempurnakan materi pendidikan agama dengan memberikan tambahan bobot pada kehidupan nyata sehari-hari;

- Memasukkan muatan budi pekerti yang terintegrasi dalam mata pelajaran yang relevan di dalam kurikulum pendidikan;

- Melakukan penataran guru, penyetaraan diploma dua (D2) dan diploma tiga (D3) guru agama;

- Menyediakan bantuan sarana peribadatan; Mengadakan lokakarya guru agama dalam rangka pendalaman materi dan pengembangan wawasan pendidikan;

- Menyempurnakan metode belajar-mengajar berikut sistem evaluasinya;

- Mengembangkan manajemen pendidikan; Mengadakan lomba keterampilan agama, perkemahan pelajar, lomba karya ilmiah agama, dan apresiasi seni keagamaan; 


\section{Badruzzaman}

- Membina dan mengembangkan bakat kepemimpinan dan penambahan pengetahuan serta pengalaman agama;

- Membina organisasikesiswaan;

- Mengembangkan pesantren kilat dan yang sejenisnya.

Program pembinaan Lembaga-Lembaga Sosial Keagamaan dan Lembaga Pendidikan Tradisional Keagamaan:

- Memberdayakan lembaga sosial keagamaan seperti kelompok jemaah keagamaan, majelis taqlim, taman pendidikan quran (TPQ) organisasi remaja dan pemuda mesjid, Baitul Mai wat - Tamwil, Badan Amil Zakat, infak dan sadakah (BAZIS) dan Nadzir Wakaf;

- Meningkatkan peran lembaga pendidikan tradisional keagamaan yang mengemban misi dakwah dan pendidikan agama bagi masyarakat;

- Memberikan subsidi dan imbal-swadaya pada lembaga pendidikan tradisional keagamaan;

- Menyediakan sarana dan prasarana, bantuan peralatan dan buku pelajaran serta buku bacaan lainnya pada lembaga pendidikan tradisional keagamaan.

5. Impelementasi Pendidikan Agama Pasca Konflik

Dalam Peraturan Pemerintah tehtang Nomor 52 tahun 2007 tentang Penddidikan Agama dan Pendidikan Keagamaan, ditegaskan tugas-tugas pemerintah dalam upaya meningkatkan kualitas Pendidikan Agama dan Pendidikan Keagamaan. Tugas-tugas pemerintah itu antara lain adalah :

- Pemerintah menyediakan satuan pendidikan, termasuk didalamnya, menyediakan tanah, gedung, sarana dan prasarana pendidikan, mengangkat guru dan adminsitrator pendidikan.

- Pemerintah menetapkan standar Pendidikan Agama dan Pendidikan Keagamaan.

- Pemerintah menetapkan standar Evaluasi Pendidikan Agama dan Pendidikan Keagamaan.

Berdasarkan ketiga tugas pemerintah tersebut maka, implementasi pendidikan agama akan diuraikan berdasarkan hal tersebut di atas terutama pada bagian pertama. 


\section{Badruzzaman}

a. Implementasi Pendidkan Agama terhadap Peningkatan Sarana dan Prasarana Pendidikan.

Peningkatan mutu sarana dan prasarana pendidikan yang telah dilakukan oleh Pemerintah Daerah di Kota Ternate tampak pada MTsN Ternate. Peningkatan kualitas sarana dan prasaran pendidikan agama tersebut dilakukan secara maksimal pada pasca kerusuhan bernuansa agama 1999. Sejumlah 91,81\% dari sarana dan prasarana yang dimiliki oleh MTsN Ternate yang diadakan dalam kurun waktu tahun 2000-2008.

Perkembangan impelentasi kebijakan pemerintah terhadap pendidikan agama di kota Ternate dalam upaya meningkatan mutu sarana dan prasarana pendidikan agama sangat tampak. Peningkatan mutu sarana dan prasarana tersebut tampak sangat dominan dilakukan pada setahun setelah kerusuhan terjadi yaitu pada tahun 2000. Sejumlah $41,77 \%$ sarana dan prasarana yang dimilik sekarang MTsN Ternate yang pengaadaannya pada tahun 2000. Setelah itu, penambahan sarana dan prasarana sebagai upaya implementasi kebijakan pemerintah di bidang pendidikan agama tampak pada tahun 2007, terdapat sejumlah 31,58\% dari sarana yang dimiliki saat ini. Perkembangan implementasi kebijakan pemerintah meningkatkan mutu sarana dan prasarana pendidikan agama yang di sasarkan pada MTsN Ternate dapat dilihat pada grafik berikut:

Grafik 1

Perkembangan Peningkatan Jumlah Sarana dan Prasarana di MTsN Ternate

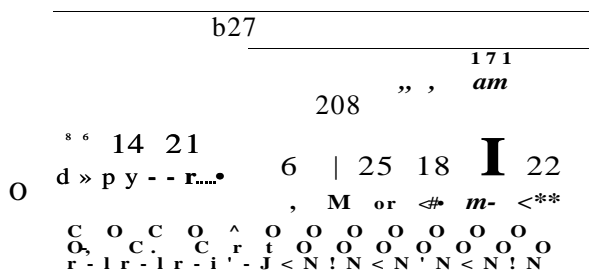

Selain di MTsN Ternate, implementasi kebijakan pemerintah terhadap peningkatan mutu sarana dan prasarana pendidikan agama juga tampak di MAN Model Ternate. Implementasi kebijakan tersebut dominan dilakukan setelah kerusuhan bernuasa agama yang terjadi di Ternate tahun 1999. Ada sejumlah $85.99 \%$ dari sarana dan prasarana yang dimiliki oleh MAN Model Ternate saat ini yang pengadaannya dilakukan pasca kerusuhan. 
Peningkatan implementasi kebijakan pemerintah terhadap peningkatan kuantitas dan kwalitas sarana dan prasarana pendidikan yang disasarkan ke MAN Model Ternate terjadi empat tahun setelah kerusuhan yaitu tahun 2004. Perkembangan kwantitas dan kwalitas sarana dan prasarana tersebut meningkat secara linier terjadi selama tiga tahun berturut-turut, yaitu pada tahun 2004,2005,2006. Dan dua tahun berikutnya, 2007 penambahan sarana dan prasarana pendidikan sebagai implementasi kebijakan pemerintah mencapai kwantitas jumlah yang lebih tinggi dari tahun tahun-tahun sebelumnya.

\section{Grafik2}

Perkembangan Peningkatan Jumlah Sarana dan

Prasarana di MAN Model Ternate

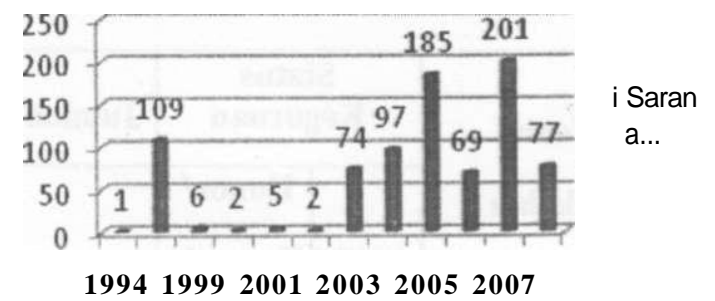

Berbeda dengan lembaga pendidikan agama Islam, lembaga pendidikan agama Kristen dan Katolik tampak tidak tersentuh implementasi kebijakan pemerintah terhadap peningkatan kuantitas dan kualitas sarana pendidikan. Sebagaimana diungkap terdahulu bahwa mayoritas lembaga pendidikan di bawah binaan penganut agama Kristen dan Katolik belum berjalan secara optimal sejak kerusuhan, bahkan terdapat yang belum beroperasi sampai saat ini. Hal ini disebabkaii oleh karena selain pengelola, guru dan siswa yang akan di sekolahkan pada lembaga tersebut belum terindentifikasi secara real, satu hal yang sangat menghalangi pengoperasian tersebut adalah sejumlah sekolah masih dipakai sebagai sarana penampungan para pengungsi muslim yang berasal dari wilayah-wilayah lain yang juga ikut rusuh seperti Pulau Halmahera, Makian, dan lain-lain. Karena itu upaya untuk mengelola secara optimal lembaga pendidikan tersebut tidak dapat dilakukan sebelum para pengungsi tersebut meninggalkan sekolah-sekolah tersebut. 


\section{Badruzzaman}

b. Implementasi Pendidikan Agama Terhadap Peningkatan Jumlah dan Kwalitas Guru

Pengangkatan guru yang ditempatkan pada lembaga pendidikan agama merupakan salah satu tugas dan kebijakan pemerintah baik pusat maupun daerah. Sampai saat ini ada sejumlah 129 orang guru yang bertugas pada lembaga pendidikan agama di Kota Ternate. Terdapat sejumlah 96 guru yang mengajar di madrasah, 27 orang di madrasah diniyah dan 4 orang di sekolah Kristen. Sedangkan status keguruan mereka adalah ada sejumlah 95 orang yang berstatus PNS, dua di antaranya yang mengajar di sekolah Kristen. Sejumlah 35 orang guru yang berstatus honorer dan mayoritas mengajar di madrasah diniyyah.

Tabel 1

Jumlah Guru di Lembaga Pendidikan Agama dan Keagamaan

\begin{tabular}{|l|r|r|r|}
\hline \multirow{2}{*}{\multicolumn{1}{|c|}{ Jenis }} & \multicolumn{2}{|c|}{$\begin{array}{c}\text { Status } \\
\text { Keguruan }\end{array}$} & Jumlah \\
\cline { 2 - 4 } & PNS & $\begin{array}{r}\text { Honor/ } \\
\text { Kontrak }\end{array}$ & \\
\hline Madrasah & 92 & 6 & 98 \\
\hline $\begin{array}{l}\text { Madrasah } \\
\text { Diniyah }\end{array}$ & & 27 & 27 \\
\hline Sekolah Kristen & 3 & 1 & 4 \\
\hline Jumlah & 95 & 35 & 129 \\
\hline
\end{tabular}

Implementasi kebijakan pemerintah terhadap penambahan jumlah guru di lembaga pendidikan agama yang tampak bertahap itu dapat dilihat pada kondisi guru di MTsN Ternate. seperti tergambar pada grafik berikut ini: 
Badruzzaman

Grafik3

Perkembangan Pengangkatan Guru PNS di MTsN Ternate

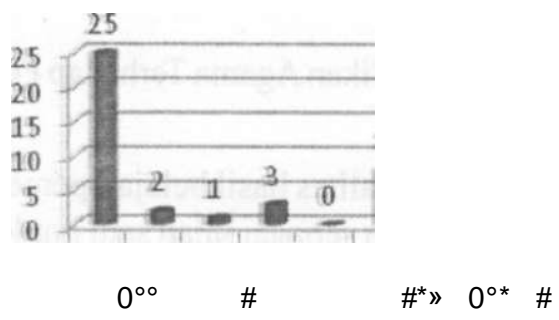

Implementasi kebijakan pemerintah terhadap penanggulangan kekurangan guru yang dialami oleh MTsN Ternate memang sangat membantu proses pembelajaran di madrasah tersebut. Namun implementasi tersebut belum juga mencapai target pemenuhan kebutuhan guru secara maksimal. MTsN Ternate masih membutuhkan guru umum sejumlah 8 orang.

Selain MTsN Ternate, MAN Model Ternate pun mendapat tambahan guru dari implementasi kebijakan pemerintah terhadap penambahan jumlah guru. Implementasi tersebut serupa pada MTsN Ternate. Hanya sejumlah 8 orang guru yang diangkat pasca kerusuhan benuasa agama 1999. Jumlah guru MAN Model saat ini adalah 46 orang.

Selain penanggulangi kekurangan guru, program yang lain sebagai implementasi kebijakan pemerintah terhadap pendidikan agama pasca kerusuhan adalah program peningkatan kesejateraan guru. Program peningkatan kesejahteraan guru merupakan program nasional. Salah satunya adalah kenaikan gaji PNS secara regular tiap tahun termasuk para guru. Tiga tahun terakhir ini pemerintah pusat melakukan perbaikan penghasilan bagi PNS dan Guru dengan mengeluarkan kebijakan kenaikan gaji di awal tahun yang rata-rata - 15\% $20 \%$. Kenaikan gaji para guru tersebut merupakan salah satu implementasi kebijakan pemerintah adalah upaya meningkatkan mutu pendidikan secara umum termasuk pendidikan agama.

Secara lokal, Pemerintah Daerah Kota Ternate pun melakukan hal yang sama, peningkatan kesejahteraan guru. Salah satu program Pemerintah Daerah Ternata dalam upaya mengimplementasikan kebijakan tehadap pendidikan agama adalah pemberikan insentif kepada guru-guru termasuk guru-guru di madrasah baik negeri maupun swasta. Pemberian insentif ini dilakukan oleh Pemda Kota 


\section{Badruzzaman}

Ternate setiap tahun, umumnya dilakukan menjelang memasuk hari raya keagamaan. Jumlah yang diberikan pun bervariasi tiap tahun, yaitu dari Rp. 300.000, -Rp. 500.000,-

c. Implementasi Kebijakan Pendidikan Agama Terhadap Peningkatan Kualitas Hasil Balajar.

Dalam upaya meningkatkan kualitas hasil belajar, pemerintah daerah telah melakukan program batuan beasiswa sebagai salah satu implementasi kebijakan pemerintah terhadap pendidikan agama. Pemerintah Daerah Kot Ternate telah aktif memberikan bantuan dana kepada siswa-siswa di lembaga pendidikan agama. Seperti misalnya Departemen Sosial Provinsi Maluku Utara telah memberikan bantuan beasiswa kepada sejumlah 12 orang siswa MAN Model Ternate. Besaran dana bantuan yang dikucurkan sejumlah Rp. 6.750.000,-.

Selian Dep. Sosial Prov. Maluku Utara, Bapeda Provinsi Maluku Utara pun pada tahun 2007 telah memberikan beasisiwa kepada sejumlah 25 orang siswa MAN Model. Besaran dana bantuan tersebut adalah sejumlah 12.500.000,.

Sedangkan BKM Dinas Kota Ternate telah memberikan bantuan beasiswa secara reguler dalam tiga tahun terakhir. Pada tahun 2005 dana bantuan tersebut dikucurkan sebanyak dua kali. Kali pertama B KM Dinas Kota telah memberikan bantuan beasiswa kepada sejumlah 24 orang siswa, dengan nilai total bantuan Rp. 4.200.000,-- Kemudian pada kali kedua BKM Dinas Kota Ternate pun memberikan bantuan beasiswa kepada sejumlah 70 orang sisiwa, besar bantuan Rp. 27.300.000,-. Pada tahun berikutnya, 2006 BKM Dinas Kota Ternate memberikan bantun beasiswa kepada siswa-siswi MAN Model Ternate sebanyak tiga kali, yaitu pertama bantuan beasiswa diberikan kepada sejumlah 24 orang siswa dengan besaran bantuan Rp. 4.200.000,-; kedua 45 orang siswa, Rp. 7.875.000,-; ketiga 135 orang siswa, Rp. 26.325.000,-.

Dinas Pendidikan Kota Ternate juga pernah memberikan bantuan beasiswa kepada siswa MAN Model pada tahun 2007. Ada sejumlah 35 orang siswa yang mendapatkan bantuan dana pendidikan saat itu. Besaran bantuan dana pendidikan yung dikucurkan oleh Dinas Pendidikan Kota Ternate adalah $5.250 .000,-$.

Departemen Agama pun telah melakukan hal yang sama dalam upaya mengimplementasikan kebijakan terhadap peningakatan hasil belajar pada lembaga pendidikan agama. Pada tahun 2005 Kantor Depag Kota Ternate telah memberikan bantuan beasiswa sebanyak dua kali. Pertama, Kandep Agama 
Kota memberikan bantuan kepada sejumlah 24 siswa dengan sebesar Rp. 3.600.000,- dan kedua diberikan kepada siswa sejumlah yang sama dan besaran dana yang sama pula.

Pada tahun 2006, Kandep Agama Kota Ternate melakukan kegiatan yang sama. Ada sejumlah 24 siswa yang diberikan beasiswa dengan tiga kali kegiatan pemberian dana bantuan pendidikan. Pertama, Kandep Agama Kota Ternate memberikan beasiswa kepada 8 orang siswa sebesar Rp. 3.120.000,-; kedua, 8 orang siswa, Rp. 1.560.000,-; ketiga, 8 orang, Rp. 1.560.000,--

Sedangkan Kanwil Departemen Agama Provinsi Maluku Utara melakukan kegiatan yang sama pada tahun 2007. Ada sejumlah 20 orang sisiwa MAN Model yang diberikan bantuan dana pendidikan dengan besaran dana Rp. $15.600 .000,-$.

Sehingga dalam tiga tahun terakhir MAN Model Ternate telah mendapatkan bantuan besar Rp. 210.290.000. besaran nilai bantuan tersebut disalurkan kepada sejumlah 912 oran siswa. Kegiatan pemberian bantuan beasisiwa ini merupakan salah satu upaya implementasi kebijakan pemerintah terhadap pendidikan agama khususnya pada upaya peningkatan kwalitas hasil belajar.

\section{PENUTUP}

1. Kesimpulan

a. Secara fisik dampak konflik bernuansa agama terhadap pendidikan agama yang terjadi di Kota Ternate, 1999, tidak tampak. Hal ini disebabkan oleh karena sasaran kerusuhan saat itu lebih kepada permukiman penduduk dan sarana-sarana ibadah. Konflik yang melibatkan dua penganut agama, Islam dan Kristen itu, kemudian berdampak terhadap proses pembelajaran di lembaga-lembaga pendidikan agama di semua jenjang pendidikan. Pada awal-awal pasca konflik, proses belajar mengajar terhenti beberapa bulan, setelah dimulai proses belajar mengajar dampak konflik yang muncul kemudian adalah bersifat psikologis yang dialami oleh baik siswa, tenaga pengajar maupun adminstrasi pendidikan. Satuan-satuan pendidikan keagamaan tersebut harus menampung para siswa yang telah mengungsi dari daerah lain sehingga muatan siswa dalam satu kelas melebihi kapasitas ideal, 60-70 orang siswa. Sementara itu, lembaga pendidikan yang dibina oleh penganut agama Kristen/Katolik, tidak mengalami kerusakan fisik, namun proses belajar-mengajar terhenti sampai saat ini. Keterhentian proses belajar-mengajar pada lembaga pendidikan agama Kristen itu lebih 


\section{Badruzzaman}

disebabkan oleh karena sekolah-sekolah mereka masih berfungsi sabagai kamp-kamp penampungan pengungsi yang sampai saat ini belum diupayakan pemulangannya ke daerah asal. Bahkan terdapat fasilitas pendidikan agama Kristen yang digunakan untuk proses pembelajaran oleh salah satu lembaga pendidikan Islam.

b. Implementasi kebijakan pemerintah terhadap peningkatan mutu pendidikan pada lembaga-lembaga pendidikan agama meningkat, pasca konflik di Kota Ternate. Walau tidak satu satuan pendidikan agama yang didirikan akan tetapi peningkatan kualitas sarana dan prasarana pendidikan pada satuansatuan pendidikan agama yang sudah tampakjelas, yaitu mencapai $40 \%$ $86 \%$ sarana pendidikan yang dimiliki oleh satuan-satuan pendidikan agama Islam saat ini pengadaannya dilakukan pasca konflik, 2000-2008. Pengangkatan gurupun demikian, dibanding sebelum kerusuhan dimana pengangkatan guru yang ditempatkan pada satuan-satuan pendidikan agama dilakukan dalam rentang 5-10 tahunan sekali pengangkatan, maka pada pasca konflik pengangkatan guru dilakukan hampir tiap tahun, walau pengangkatan tersebut dilakukan dilakukan secara sporadis (dalam jumlah yang banyak) akan tetapi secara bertahap untuk menanggulangi kekurangan guru yang terjadi selama ini. Demikian halnya dengan pemberian beasiswa terhadap sejumlah siswa. Beberapa departemen yang telah ikut memberikan beasiswa kepada sejumlah siswa setiap tahun, seperti BKM Dinas Kota Ternate, Dinas Pendidikan Kota Ternate, Kanwil Agama Prov. Maluku Utara dan Kandep Agama Kota Ternate, sehingga dana beasiswa yang telah tersalurkan pada konflik, tahun 2000 sampai saat ini adalah sejumlah di atas Rp. 310.390.000,-.

\section{Rekomendasi}

a. Penganggulangan dampak konflik terhadap proses pendidikan segara dilakukan, terutama terhadap sarana-sarana pendidikan yang masih difungsikan sebagai fasilitas para korban konflik. Pihak berwenang diharapkan segera mengambil kebijakan berkaitan dengan itu, seperti upaya pemulangan para pengungsi ke daerah asal atau penyediaan lahan permukiman yang peruntukkan bagi para korban konflik, agar saranasarana pendidikan yang difungsikan untuk itu segera digunakan. Demikian halnya dengan kebijakan berkiatan dengan pengaktifan kembali satuansatuan pendidikan agama yang selama ini terhenti akibat konflik. Dukungan pihak yang berwenang terhadap pengaktifan tersebut dapat berupa, 


\section{Badruzzaman}

pemberian jaminan keamanan bagi masyarakat tertentu (siswa, orang tua siswa, pengelola satuan pendidikan, dan guru yang tergolong korban dampak konflik) untuk aktif terlibat dalam proses pendidikan, pemberian bantuan rehabilitasi sarana dan prasarana, dan kebijakan pengangkatan guru yang ditempatkan pada satuan-satuan pendidikan yang terkena dampak konflik.

b. Peningkatan sarana dan prasarana pendidikan perlu dipertahankan. Namun kebijakan peningkatan tersebut seyogyanya dilakukan dengan asas pemerataan dengan memperhatikan keragaman etnik, agama, dan status sosial. Kebijakan peningkatan sarana dan prasarana pendidikan hendakhnya disarankan juga kepada satuan-satuan pendidikan yang dikelola oleh etnik, penganut agama dan status sosial tertentu. Demikian halnya dengan pengangkatan tenaga pengajar dan administrator pendidikan, hendaknya mempertimbangakan ketiga keragaman tersebut terdahulu.

c. Upaya untuk memberikan pemahaman yang bernuansa multikultural kepada semua komponen pendidikan segera dilakukan, baik kepada administrator pendidikan (pejabat dan calon pejabat di bidang pendidikan dan pimpinan satuan pendidikan), guru sampai kepada siswa, segera dilakukan. Bagi administrator pendidikan pemberian pemahaman nuansa multikultural dapat dilakukan dengan diklat-diklat tertentu, sedangkan bagi siswa dilakukan dalam proses belajar mengajar. Karena itu pengkajian materi multikultural urgen untuk dilakukan dengan mempertimbangkan karakteristik sosial budaya dimana materi tersebut akan diajarkan. Pengkajian tersebut dapat dilakukan dengan riset model pembelajaran multikultural. 


\section{Badrtizzaman}

\section{DAFTAR PUSTAKA}

Badan Pusat Statistik Kota Ternate, 2004, Kota Ternate Dalam Angka 2004, BPS Kota Ternate. , 2006, Kota Ternate Dalam Angka 2005-2006, BPS Kota Ternate. , 2007, Kota Ternate Dalam Angka 2007, BPS Kota Ternate.

M. Arifin, H, Prof. MEd. 1993, Ilmu Pendidikan Islam, Penerbit Bumi Aksara, Jakarta.

Penerbit PT Kreasi Jaya Utama, 1989, Undang-Undang Sistem Pendidikan Nasional, Nomor 2 Tahun 1989.

Peraturan Pemerintah RI Nomor 55 Tahun 2007 tentang Pendidikan Agama dan Pendidikan Keagamaan, Foto copy SK Presiden RI Nomor 55 Tahun 2007.

Sabari, M. Alisuf, H., Drs. 1989, Ilmu Pendidikan, Pedoman Ilmu Jaya, Jakarta.

Sutari, Imam Bamadib, Prof. Dr., 1989, Pengantar Ilmu Pendidikan Sistimatis, Penerbit Andi Offset, Yogyakarta.

Yusuf, A. Muri, Drs., 1997, Pengantar Ilmu Pendidikan, Penerbit Ghalia Indonesia, Jakarta. 